\title{
Comparative toxicity of selected naphthenic acids, oil sands processed water and surface waters in rainbow trout hepatocytes: A gene expression study
}

\author{
Gagné F*, André C, Turcotte P, Gagnon C
}

Aquatic Contaminants Research Division, Environment and Climate Change Canada, 105 McGill Street, Montreal, Quebec, Canada

Received: 03 December, 2016; Accepted: 14 December, 2016; Published: 26 December, 2016

*Corresponding author: F. Gagné, Aquatic Contaminants Research Division, Environment and Climate Change Canada, 105 McGill Street, Montreal, Quebec, Canada, E-mail: francois.gagne@canada.ca

\begin{abstract}
This study examined the cytotoxic properties of selected naphthenic Acids (NA), commercial mixtures of NA in rainbow trout hepatocytes and compares the responses with Oil Sand Processed Water (OSPW) and river water extracts. Hepatocytes were exposed to increasing concentrations of selected NAs $(\mathrm{z}=0,2,4,6,8$ and 10), 2 commercial mixtures of NA, 2 OSPW, and surface waters upstream and downstream from the Athabasca River at an OS development area (Alberta, Canada) for $48 \mathrm{~h}$ at $15^{\circ} \mathrm{C}$. Cell viability, total RNA levels and the expression of 15 gene transcripts involved in biotransformation (CYP1A1, CYP3A4, GST and MDR), oxidative stress (SOD, CAT, GST), DNA damage/repair (UNG, APEX, LIG, GADD45, OGG), estrogenicity (VTG and ER2), cell growth (PCNA, GADD45), and glycolysis (GAPDH) were determined. Individual NAs induced the expression most of the genes, except for GST, whose expression was reduced. For NA mixtures, the most sensitive genes were those involved in DNA repair (APEX, LIG, GADD45, and OGG) and biotransformation (CYP1A1 and 3A4). The same pattern was observed for OSPW, except that MDR was the most sensitive gene, and GST gene expression was decreased as occurred with NAs. The responses for river water samples were generally lower than for OSPW, NAs and NA mixtures, and involved biotransformation (GST and MDR) genes, DNA repair (OGG, LIG) genes and potential endocrine disruption (ER2). Canonical analysis of gene expression data and cell viability revealed that genes involved in Xenobiotic metabolism, oxidative stress and DNA damage (repair) were strongly correlated with cytotoxic effects. Decision tree analysis revealed that these compounds separated into 4 distinct clusters (OSPW, upstream and downstream river water, NA mixtures), whereas the individual NAs were generally found in the OSPW cluster. OSPW and NA mixtures showed distinct properties from surface waters collected downstream from the OS development area suggesting that OSPW did not overly contaminated river waters.
\end{abstract}

Keywords: Oil sands; Hepatocytes; Oncorhynchus mykiss; Biotransformation; Genotoxicity; Endocrine Disruption; Oxidative Stress; Cytotoxicity

\section{Introduction}

The Athabaska River (Alberta, Canada) stretches 1,200 km from northern Alberta through the Northwest Territories to the Mackenzie River estuary. It drains an area rich in Oil Sands (OS) deposits and is considered one of the world's largest oil reserves with an estimated yield of 27 billion cubic meters of crude oil [1]. OS consist of about $10 \%$ bitumen and $5 \%$ water, with the remainder being sand and clay. The extraction process involves adding hot caustic water to OS under aeration to separate bitumen from the OS (Clark extraction process). The crude oil fraction, which partitions at the surface, is then further extracted with the addition of solvents (naphtha, toluene) to yield a more concentrated non-polar fraction. The remaining water and sediment deposits constitute the OSPW, which is released into large tailing ponds covering many square kilometers. Numerous contaminants are found in OSPW, including a number of alkaliextractable compounds such as Naphthenic Acids (NAs), polyaromatic and aliphatic hydrocarbons and various inorganic elements such as sodium, vanadium, strontium, calcium, nickel and sulfates [2-4].Recent evidence has shown that OS mining activity was associated with increased releases of dissolved PAHs and heavy metals, which raised concerns about the ecotoxicological consequences of these activities [5-6]. NAs are cyclic aliphatic hydrocarbons that can reach concentrations as high as $50 \mathrm{mg} / \mathrm{L}$ in tailing ponds [7]. NAs follow the $\mathrm{C}_{\mathrm{n}} \mathrm{H}_{2 \mathrm{n}-\mathrm{a}} \mathrm{O}_{\mathrm{x}}$ rule which comprise at least one carboxylic acid and they are suspected to be a major component of OSPW toxicity. However, the presence of NAs has been observed in runoff waters (leachates) from OS storage sites, indicating that OSPW is not the only source of NA in the environment [8]. This highlights the difficulty of identifying specific markers of OSPW in the environment at low levels, although the highest concentrations of NAs are found in OSPW.

The toxicity of OSPW to aquatic organisms has received increasing attention over the last decade. Toxicity has been examined at various levels, including endocrine disruption, DNA damage, immune competence, biotransformation and reproduction. Goldfish exposed to OSPW for 12 weeks showed elevated expression of pro inflammatorygenes such as interleukin$1 \beta$ and tumor necrosis factor 2 in the spleen and kidneys [9]. This 
led to decreased ability of head kidney macrophages to produce reactive oxygen species, which normally follows phagocytosis of bacteria. In a study with fathead minnows exposed to OSPW, lower plasma 11-ketotestosterone levels and gonado-somatic indices were observed [10]. There were also signs of epithelium degeneration in gills of fish exposed to OSPW compared to reference fish, supporting the notion that the toxicity of OSPW is diverse and not specific to a target organ. This was corroborated by another study, which examined the health status of white suckers exposed to aged OS tailings [11]. Fish maintained in aged OSPW had smaller testes and ovaries and reduced growth, which resulted from limited available energy and endocrine disruption, which was associated with increased CYP1A1 activity in the liver. The first evidence of endocrine disruption based on the Vitellogenin (VTG) pathway was reported by Gagné, at al. [12]. VTG gene expression was induced in trout hepatocytes exposed to surface waters located upstream and downstream from the OS development area as well as to OSPW. Induction was higher in cells exposed to OSPW compared to surface waters, which suggests that OSPW is estrogenic. In a previous study, however, it was found that sea water leachates from oil rigs did not increase mosquito fish plasma VTG [13]. OPSW was shown to be genotoxic to rainbow trout hepatocytes based on the alkaline DNA precipitation and comet assays $[14,15]$. In addition to OSPW and NA commercial mixtures, DNA damaging compounds were ubiquitous in both upstream and downstream surface waters, which suggest that a number of chemicals contributed to the observed genotoxicity of OS. The multi-drug ATP binding cassette transporter (MDR) was also influenced by OS-related compounds and is involved to the efflux of potentially toxic hydrocarbons from cells. The effects of the soluble fraction of OSPW on MDR transport activity were examined in Japanese medaka fry [16]. It was found that the neutral and basic fractions of OSPW inhibited the extrusion of calcein dye in fry, which suggests that MDR activity could be inhibited and limit the elimination of organic contaminants in fish exposed to OS in the environment. These fractions were shown to contain higher levels of oxygen-, sulfur-, and nitrogen-containing hydrocarbons. This study corroborated earlier findings that MDR gene expression was inhibited in hepatocytes exposed to OSPW but not by OS leachates [17]. A better understanding of OSPW-specific toxic effects from the natural leaching of OS compounds would provide more information on the fundamental ecotoxicological impacts of industrial extraction in the Athabasca watershed. Recent evidence suggests that OSPW is more toxic than passive OS water leachates in the river. For example, a study of the phytotoxicity of laboratory-prepared OSPW and of OS leachates revealed that OSPW contained more light PAHs (naphthalene-like), vanadium, aluminum and chromium than did OS leachates [18]. A study compared the toxic properties of OSPW and OS leachates using primary cultures of rainbow trout hepatocytes [17]. It found that some gene transcripts were more specific to OSPW and either did not respond or respond slightly to OS leachates; these were superoxide dismutase (SOD), glutathione S-transferase (GST), CYP3A4, glyceraldehyde-3-phosphate dehydrogenase, a marker of anaerobic glycolysis, and two genes involved in DNA repair (GADD45 and APEX). DNA repair genes responded to OS leachates, albeit less strongly than they did to OSPW. Moreover, gene transcripts that were associated with cell viability were chosen on the basis of their implication in cell mortality. It was found that genes involved in biotransformation were closely related to cytotoxicity. Although these genes appeared to be specific to OSPW but not to OS leachate, they were not compared with selected NAs or commercial NA mixtures to identify similarities with OSPW and determine whether surface waters upstream and downstream from the OS mining area display similar toxic properties to OSPW and NAs.

The purpose of the study was to compare the response profiles of gene transcripts in rainbow trout hepatocytes exposed to a selection of individual NA-like compounds of increasing molecular size ( $\mathrm{z}$ value), commercial mixtures of NA, OSPW and surface water samples collected in locations upstream and downstream from the OS mining area. We hypothesized that the upstream and downstream waters are similar (no influence from mining activities) and that OPSW cannot be explained only by NAs or commercial NA mixtures (null hypothesis). The gene transcripts were chosen based on the results of previous studies on OSPW, OS leachates and surface water. Cytotoxicity was examined at the membrane integrity level in addition to biotransformation, oxidative stress, genotoxicity (DNA repair), anaerobic glycolysis, endocrine disruption (estrogenicity) and cell maintenance/growth. Primary cultures of fish hepatocytes are recognized models for toxicity investigations involving biotransformation [19]. An attempt was made to find common trends in gene expression profiles for OSPW, individual NAs, commercial mixtures of NAs and downstream surface waters in the Athabasca River in a region where industrial OS extraction operations are carried out.

\section{Materials and methods}

\section{Naphthenic acids, oil sands processed water and surface water collection preparation}

A selection of NA-like compounds and commercial NA mixtures were used in this study in addition to OSPW and surface waters (Table 1). Six mono-carboxylic acid chemicals following the $\mathrm{C}_{n} \mathrm{H}_{2 n-\mathrm{z}} \mathrm{O}_{2}$ rule were chosen based on increasing $\mathrm{z}$ values $\mathrm{z}=$ $0,2,4,6,8,10)$. They were purchased from Sigma-Aldrich and dissolved in absolute ethanol at a concentration of $10 \mathrm{mg} / \mathrm{ml}$. The exposure concentrations were 2, 10, 50 and $100 \mathrm{ug} / \mathrm{ml}$ at a final $0.2 \%$ ethanol concentration. Two commercial NA acid mixtures were also tested: one from Sigma-Aldrich (Na mixture 1) and one from Thermo-Fisher Scientific (Na mixture 2, ACROS Organics brand). The stock solution was diluted in absolute ethanol, and the following concentrations were used at a final absolute ethanol concentration of $0.2 \%: 2,10,50$ and $100 \mathrm{ug} / \mathrm{ml}$.

OSPW and surface water samples were collected in the Athabasca River near the OS extraction sites. OSPW samples 1 and 2 correspond to two different OS tailing ponds. The surface waters consisted of samples from the upstream site (in the Athabasca River, $10 \mathrm{~km}$ downstream from Fort McMurray) and the OS area (along the western shore of the Athabasca 


\begin{tabular}{|c|c|c|c|}
\hline Naphthenic acid & Chemical formula / MW & $\mathrm{Z}$ value & Structure \\
\hline Decanoic acid & $\mathrm{C}_{10} \mathrm{H}_{20} \mathrm{O}_{2}$ & 0 & \\
\hline Cyclohexanepentanoic acid & $\mathrm{C}_{11} \mathrm{H}_{20} \mathrm{O}_{2}$ & -2 & \\
\hline 2-(1-cyclohexenyl)-butyric acid & $\mathrm{C}_{10} \mathrm{H}_{16} \mathrm{O}_{2}$ & -4 & \\
\hline 3-Noradamantanecarboxylic acid & $\mathrm{C}_{10} \mathrm{H}_{14} \mathrm{O}_{2}$ & -6 & \\
\hline $5 \beta$-Cholanic acid & $\mathrm{C}_{24} \mathrm{H}_{40} \mathrm{O}_{4}$ & -8 & \\
\hline Abietic acid & $\mathrm{C}_{20} \mathrm{H}_{30} \mathrm{O}_{2}$ & -10 & \\
\hline
\end{tabular}

River opposite the Steep bank River outfall) as well as samples taken at the confluence of the Muskeg and Ells rivers. A volume of $120 \mathrm{~L}$ was collected, mixed and sent to various laboratories dark containers at $4^{\circ} \mathrm{C}$. Upon receipt (within $24 \mathrm{~h}$ ), the water samples were filtered on a sterile 0.45 -um pore polycarbonate filter and a $500-\mathrm{mL}$ volume was passed through a C18 solidphase mini-column (Sep-Pak C18, $360 \mathrm{mg}$, Waters Associates Inc.). The columns were pre-conditioned with $2 \mathrm{~mL}$ of absolute ethanol and $10 \mathrm{~mL}$ of distilled water at 5 psi. After passing the water or OSPW samples, the columns were washed with $10 \mathrm{~mL}$ of bidistilled water and eluted with $15 \mathrm{~mL}$ of analytical grade absolute ethanol (Sigma Chemical Company, ON, Canada). The ethanol fraction was reduced to $5 \mathrm{~mL}$ under a nitrogen stream to obtain a $100 \times$ concentration factor and was then kept at $-20^{\circ} \mathrm{C}$ in the dark until analysis. The exposure concentrations were $0.004 \%, 0.02 \%, 0.1 \%$ and $0.5 \%$, which corresponded to $0.4 \%$, $2 \%, 10 \%$ and $50 \%$ of the original water samples. The maximum ethanol concentration was at $0.5 \%$, and constituted the solvent control. The OSPW and surface water extracts were analyzed for polyaromatic hydrocarbons by fixed wavelength fluorescence spectroscopy, as previously described [14]. The light, medium and heavy PAHs were expressed as $\mu \mathrm{g} / \mathrm{L}$ naphthalene, pyrene and benzo (a) pyrene equivalents, respectively.

\section{Preparation and exposure of rainbow trout hepatocytes}

Primary cultures of rainbow trout (Oncorhynchus mykiss) hepatocytes were prepared using the double perfusion methodology [20]. In summary, young-of-the-year rainbow trout (10-15 cm fork length) were euthanized in $100 \mathrm{mg} / \mathrm{L}$ tricaine methanesulfonate buffered with $\mathrm{NaHCO}_{3}$ at $\mathrm{pH} 7$ for 5 min, as recommended by the Canadian Council on Animal Care Committee. The livers from 5 individuals were first perfused with $10 \mathrm{mM}$ EDTA in phosphate-buffered saline (PBS: $140 \mathrm{mM}$ $\mathrm{NaCl}, 5 \mathrm{mM} \mathrm{KH}_{2} \mathrm{PO}_{4}$ and $1 \mathrm{mM}$ glucose, $\mathrm{pH}$ 7.4) for $10 \mathrm{~min}$ at room temperature. The livers were then minced in $100 \mathrm{U} / \mathrm{mL}$ collagenase in PBS (without EDTA) containing $1 \mathrm{mM} \mathrm{CaCl}$ and $0.05 \%$ serum bovine albumin for $30 \mathrm{~min}$ at room temperature. The samples were then passed through a $50-\mu \mathrm{m}$ sieve and centrifuged at $200 \times g$ for $5 \mathrm{~min}$. The cell pellets were then re suspended in Liebovitz (L - 15) cell culture media containing $10 \%$ Fetal Bovine Serum (FBS), antibiotics and antimycotics (100 $\mu \mathrm{g} / \mathrm{mL}$ of streptomycin, $100 \mathrm{U} / \mathrm{mL}$ of penicillin, and $0.25 \mu \mathrm{g} /$ $\mathrm{mL}$ of amphotericin B) for cell counting and viability assessment as described below. The cells were then washed 2 more times (centrifugation-resuspension) without FBS, resuspended in L15 without FBS and plated at a density of 1 million live cells/mL in 48-well micro plates in L-15 media. The initial cell concentration and viability were determined using trypan blue staining $(0.004 \%)$ and examination on a hematocytometer at $200 \times$ under a microscope after $10 \mathrm{~min}$. The hepatocytes were exposed to the compounds and extract samples, as described above, at $15^{\circ} \mathrm{C}$ for $48 \mathrm{~h}$ under saturated humidity in the dark; control cells included ethanol at $0.2 \%$ or $0.5 \%$. After the exposure period, the micro plates were centrifuged at $150 \times g$ for $5 \mathrm{~min}$ at $4^{\circ} \mathrm{C}$, and the media were removed by aspiration and the cells resuspended in PBS. Cell viability was determined using trypan blue, as described above. A $250-\mu \mathrm{L}$ portion of the cell suspension was immediately mixed in the same volume of an RNA stabilizing solution (RLT 
plus buffer; Quiagen). The mixtures were placed on a QIA shredder spin column and centrifuged at $400 \times g$ for $2 \mathrm{~min}$. The supernatant was then stored at $-80^{\circ} \mathrm{C}$ until analysis for total RNA and the15 gene transcripts described below.

\section{Gene expression determinations using real-time poly- merase chain reaction}

Total RNA levels were extracted using commercial extraction kits, as described previously [12]. RNA concentrations (260 nm) and purity $(260 \mathrm{~nm} / 280 \mathrm{~nm}$ ratio < 1.8) were estimated with the NanoDrop 1000 UV-Vis Spectrophotometer (Thermo Fisher Scientific, ON, Canada). RNA integrity was verified using a micro fluidic-based electrophoresis system (Experion Automated Electrophoresis System; Bio-RAD, ON, Canada). Reverse transcription of RNA was performed using the QuantiTect reverse transcription commercial kit from QIAGEN (Toronto, ON, Canada), which ensured the complete removal of genomic DNA. The incubation temperature was $42^{\circ} \mathrm{C}$ for 15 min followed by $95^{\circ} \mathrm{C}$ for $3 \mathrm{~min}$. The cDNA samples produced were stored at $-80^{\circ} \mathrm{C}$ until real-time quantitative Polymerase Chain Reaction (qPCR) analysis. The selected genes that were quantified in this study are highlighted in Table 2. The genes were grouped under oxidative stress, biotransformation, genotoxicity (DNA repair), endocrine disruptors and others (proliferation and anaerobic glycolysis). Genes involved in oxidative stress were catalase (CAT), super oxide dismutase (SOD) and 8-oxoguanine glycosylase (OGG), which is also a marker for genotoxicity. DNA repair genes were apurinic/apyrimidinic endonuclease 1 (APEX), growth-arrest DNA damage inducible protein (GADD45), DNA ligase (LIG), uracil DNA glycosylase (UNG) and OGG, as mentioned above. Genes involved in biotransformation were cytochrome P4501A1 (CYP1A1), cytochrome P4503A4 (CYP3A4), glutathione S-transferase (GST) and multidrug P-glycoprotein pump (MDR). For endocrine disruption, vitellogenin (VTG) and estradiol-17 $\beta$ Receptor 2 (ER2) were determined. Cell proliferation and a marker of anaerobic glycolysis were determined by proliferation nuclear antigen (PCNA) and glyceraldehyde-3-phosphate Dehydrogenase (GAPDH), respectively. Reference genes used in this study were elongation factor $1 \alpha(\mathrm{EF} 1 \alpha)$, RNA polymerase 1 (RPL), prolylpeptidyl isomerase 1 (PP1A) and hypoxanthine phosphoribosyl transferase concentrations (i.e., no significant increase in baseline mortality) was selected for normalization.

Primers were designed using NCBI's Primer-BLAST (Primer3 with Blast) and Net Primer (Bio soft, Palo Alto, CA) to avoid secondary structures. The selected primer sequences were then synthesized by Integrated DNA Technologies (Coralville, Iowa, USA) and reported in Table 3. The qPCR reactions were performed using the iQ SYBR Green Super Mix (Bio-Rad, Mississauga, On, Canada) and a real-time thermocycler (Master cycler ep realplex2; Eppendorf). All reactions were run in duplicate and consisted of $5 \mathrm{uL}$ of cDNA (equivalent to $20 \mathrm{ng} \mathrm{cDNA}$ ), $12.5 \mu \mathrm{L}$ of iQ SYBR Green Super Mix, $0.2 \mathrm{mM}$ of each dNTP, $25 \mathrm{U} / \mathrm{mL}$ of iTaq DNA polymerase, $3 \mathrm{mM}$ of $\mathrm{MgCl}_{2}$, and $10 \mathrm{nM}$ of SYBR Green I, primer concentrations of $300 \mathrm{nM}$ each, and DEPC-treated water (Ambion), and were completed to $25 \mu \mathrm{L}$. Temperature cycles were $95^{\circ} \mathrm{C}$ for $2 \mathrm{~min}$, then 40 cycles at $95^{\circ} \mathrm{C}$ for $15 \mathrm{~s}, 60^{\circ} \mathrm{C}$ for 15 $\mathrm{s}$, and $68^{\circ} \mathrm{C}$ for $15 \mathrm{~s}$. A melting curve analysis was performed to check for lack of amplification specificity; the temperatures used were $95^{\circ} \mathrm{C}$ for $15 \mathrm{~s}$, lowered to $57^{\circ} \mathrm{C}$ and increased to $95^{\circ} \mathrm{C}$ after $10 \mathrm{~min}$.

\section{Data analysis}

For gene expression data, quantification Cycle (Cq) values were imported from the real-time thermo cycler instrument to the Genex Pro software (v. 5.4.0.512; Multi D Analyses, AB, Goteborg, Sweden). The selected reference gene, EL1 $\alpha$, was analyzed using the Norm finder [21] algorithms included in the Genex software and served to calculate relative expression. The cells were exposed to $n=8$ replicates of the samples at each treatment concentration. The gene expression data relative to reference gene were finally normalized against the ethanol solvent control. Homogeneity of variance and normality were checked using Levene's test and the Shapiro-Wilk test. The data were then subjected to analysis of variance and the critical difference from the controls was determined using Fischer's Least Square Difference test. Pearson-moment correlation analysis was performed between gene expression changes and cytotoxicity data (cell viability and total RNA levels) for all the tested samples. Canonical correlations were also performed to find relationships between cytotoxicity endpoints (cell viability and total RNA levels) and genes involved in biotransformation (CYP1A1, CYP3A4, GST, MDR), oxidative stress (SOD, CAT, OGG), DNA repair/damage (UNG, LIG, APEX, GADD45 and OGG), endocrine disruption (ER2 and VTG), anaerobic glycolysis (GAPDH) and cell proliferation (PCNA). The global properties of the individual NAs, NA mixtures, OSPW, and upstream/downstream surface waters were analyzed using classification and regression (decision) trees (CART) to determine differences (specific rules) between samples. Significance was set at $\alpha=0.05$ and all tests were run using the Statistica software (version 8, France).

\section{Results}

Rainbow trout hepatocytes were exposed to individual compounds of increasing molecular size $(\mathrm{z})$ based on the general formula for naphthenic acids: $\mathrm{C}_{\mathrm{n}} \mathrm{H}_{2 \mathrm{n}-\mathrm{z}} \mathrm{O}_{2}$ (Table 2). The $\mathrm{z}$ values ranged from 0 to 10 ; the $\mathrm{z}=6$ was a diamonid (noradamantane carboxylic acid), a fused tricyclic carboxylic acid. The $\mathrm{z}=8$ compound was cholanic acid, a derivative of steroids such as cholesterol that can be found in decomposed matrices derived from living matter. The same observation holds for the $\mathrm{z}=10$ compound, abietic acid, a phyto steroid derived from plants and trees. Basic physico-chemical characteristics of the surface water and OSPW samples are reported in Table 4. The $\mathrm{pH}$ of the water samples was slightly alkaline with $\mathrm{pH}$ values between 8.5 and 8.8. The OSPW samples had a $\mathrm{pH}$ of $9-9.2$. Water conductivity varied between 275 and $300 \mu \mathrm{S}^{*} \mathrm{~cm}^{-1}$ at both the upstream and downstream sites. The conductivity at the Muskeg River confluence was $410 \mu \mathrm{S}^{*} \mathrm{~cm}_{-1}$ which was still below the values for OSPW $\left(2200 \mu \mathrm{S}^{*} \mathrm{Cm}-1\right)$. The suspended matter was between 10 and $25 \mathrm{mg} / \mathrm{L}$ with an increasing upstream/downstream trend and reached values of $300-400 \mathrm{mg} / \mathrm{L}$ in downstream samples. The 
Table 2: Selected gene targets for toxicogenomic analysis in rainbow trout hepatocytes

\begin{tabular}{|c|c|c|}
\hline Target genes & Symbol & Function/role \\
\hline $\begin{array}{l}\text { APEX nuclease } \\
\text { (multifunctional DNA } \\
\text { repair enzyme) }\end{array}$ & APEX & Genotoxicity, DNA repair \\
\hline Catalase & CAT & $\begin{array}{l}\text { Oxidative stress, hydrolysis of } \\
\mathrm{H} 2 \mathrm{O} 2\end{array}$ \\
\hline Cytochrome P450 1A & CYP1A & $\begin{array}{l}\text { Biotranformation, hydroxylation } \\
\text { of coplanar polycyclic aromatic } \\
\text { compounds }\end{array}$ \\
\hline Cytochrome P450 3A & CYP3A & $\begin{array}{l}\text { Biotransformation, } \\
\text { hydroxylation of polycyclic } \\
\text { aliphatic hydrocarbons }\end{array}$ \\
\hline Estradiol receptor $\beta 2$ & ER & $\begin{array}{l}\text { Endocrine disruption, estrogen } \\
\text { receptor }\end{array}$ \\
\hline $\begin{array}{l}\text { growth arrest and DNA- } \\
\text { damage-inducible, alpha }\end{array}$ & GADD45 & $\begin{array}{l}\text { Genotoxicity, DNA repair } \\
\text { activity }\end{array}$ \\
\hline $\begin{array}{l}\text { Glyceraldehyde 3P } \\
\text { dehydrogenase }\end{array}$ & GAPDH & Anaerobic glycolysis \\
\hline Glutathion-S-Transferase-P & GST & $\begin{array}{l}\text { Biotransformation, conjugation } \\
\text { of polar hydrocarbons }\end{array}$ \\
\hline DNA ligase & Ligase & $\begin{array}{l}\text { Genotoxicity, DNA repair } \\
\text { activity }\end{array}$ \\
\hline $\begin{array}{l}\text { 8-oxoguanine DNA } \\
\text { glycosylase }\end{array}$ & OGG & $\begin{array}{l}\text { Genotoxicity and oxidative } \\
\text { stress, DNE repair of oxidized } \\
\text { nucleotides (8-oxoguanine) }\end{array}$ \\
\hline $\begin{array}{l}\text { Proliferating cell nuclear } \\
\text { antigen }\end{array}$ & PCNA & Cell division \\
\hline P-glycoprotein (Abcb1) & pGP & $\begin{array}{l}\text { Phase III « biotransformation ", } \\
\text { involved in the extrusion of } \\
\text { polar hydrocarbons }\end{array}$ \\
\hline $\begin{array}{l}\text { Superoxide dismutase }(\mathrm{Cu} / \\
\text { Zn cytosolic) }\end{array}$ & SOD & $\begin{array}{l}\text { Oxidative stress, oxygen radicals } \\
\text { transfer for } \mathrm{H} 2 \mathrm{O} 2 \text { genesis }\end{array}$ \\
\hline uracil-DNA glycosylase & UNG & $\begin{array}{l}\text { Genotoxicity, DNA repair } \\
\text { activity. }\end{array}$ \\
\hline Vitellogenin & Vtg & $\begin{array}{l}\text { Endocrine disruption, egg yolk } \\
\text { protein precursor under the } \\
\text { control of the estrogen receptor }\end{array}$ \\
\hline \multicolumn{3}{|l|}{ Reference genes } \\
\hline Prolylpeptidyl isomerase I & PPIA & $\begin{array}{l}\text { Significantly affected, not } \\
\text { selected for normalization }\end{array}$ \\
\hline $\begin{array}{l}\text { Hypoxanthine } \\
\text { phosphoribosyl } \\
\text { transferase I }\end{array}$ & HPRT & $\begin{array}{l}\text { Significantly affected, not } \\
\text { selected for normalization }\end{array}$ \\
\hline RNA polymerase I & RPL & $\begin{array}{l}\text { Significantly affected but } \\
\text { fairly. Could be used for } \\
\text { normalization }\end{array}$ \\
\hline Elongation factor I $\alpha$ & EFI $\alpha$ & $\begin{array}{l}\text { Least significantly affected, used } \\
\text { for normalization }\end{array}$ \\
\hline
\end{tabular}

same was observed for dissolved organic carbon (DOC) content, which was $4 \mathrm{mg} / \mathrm{L}$ for the upstream site and increased to 7-12 $\mathrm{mg} / \mathrm{L}$ at downstream sites. The DOC value for the OSPW was one order of magnitude higher than the surface water reaching 140 $\mathrm{mg} / \mathrm{L}$. The proportion of light PAHs in relation to total PAHs was determined by fixed wavelength spectroscopy. The proportion of light PAHs, expressed as naphthalene equivalents of surface waters, varied between $40 \%$ and $51 \%$, whereas the downstream Ells River confluence had the highest proportion at 51\%. The proportion of light PAHs in the OSPW extract reached $72 \%$, with a mean value of $81 \%$ for commercial NA mixtures. This suggests that commercial NA mixtures and OSPW contain high levels of light PAHs such as naphthalene. Based on the above data, there is an upstream-downstream trend in suspended matter, DOC and percent of light PAHs Table 4.

The toxicity of the individual compounds, NA mixtures, OSPW and surface waters were investigated in rainbow trout hepatocytes (Figures 1A-1F). Toxicity was determined by loss of membrane permeability (try pan blue staining) and totals RNA levels were used as a general indicator of cell activity. With regard to the individual compounds, $\mathrm{z}=0$ and $\mathrm{z}=2$ were the most toxic compounds based on cell viability (Figure $1 \mathrm{~A}$ ). Interestingly, the $\mathrm{z}=0$ and $\mathrm{z}=2$ compounds were more toxic than the equivalent amount of both NA commercial mixtures. Based on total RNA levels, all compounds significantly influenced RNA levels but in a different manner (Figure 1B). Compounds $\mathrm{z}=0$ to $\mathrm{z}=6$ increased total RNA levels at the lowest concentration $(2 \mathrm{mg} /$ L) compared with a decrease in RNA levels at concentrations $>10$ $\mathrm{mg} / \mathrm{L}$. However, compounds $\mathrm{z}=8$ to $\mathrm{z}=10$ and the 2 commercial mixtures of NAs decreased total RNA levels at all concentrations tested. The toxicity of 2 OSPW samples was assessed; they were similarly toxic as they both increased cell mortality at a concentration of $0.5 \%$ (Figure 1C). This corresponds to the original concentration of $50 \%$ given that a $100 \times$ concentrate of the water/OSPW extract was used. At the total RNA level, the two samples both increased RNA levels at the lowest concentration $(0.4 \%$ of original concentration) with a decreasing effect as the concentration reached $50 \%$ dilution (Figure 1D). This suggests that acute lethality is likely to occur at low OSPW dilutions, while changes in total RNA levels can be detected at $0.4 \%$. Exposure to surface water extracts did not produce any appreciable changes in cell viability (Figure 1E). Total RNA levels were generally increased at $0.02 \%$ (or $2 \%$ of the original sample) with a trend of stronger responses for downstream sites in the OS area (i.e., decreased levels of total RNA) but with increased total RNA levels for the confluence of Ells River site. Correlation analysis between cell viability and RNA levels revealed that total RNA levels were significantly correlated with cell viability $(r=0.53 ; p<0.001)$.

Gene expression was investigated in hepatocytes exposed to individual compounds, NA mixtures, OSPW and surface water extracts (Table 4). The individual NA compounds from $\mathrm{z}$ $=0$ to $\mathrm{z}=10$ and the 2 commercial NA mixtures affected gene expression levels for the 15 target genes (Table 4). Xenobiotic biotransformation genes were generally up regulated but were down regulated with GST for all NAs $(\mathrm{z}=0$ to $\mathrm{z}=10)$. CYP3A4 gene expression, which is involved in the biotransformation of cyclic aliphatic compounds, was down regulated for the $\mathrm{z}=10$ compound. The biggest changes (based on the fold response/ concentration ratio) were observed with CYP1A1 for the $\mathrm{z}=10$ compound and commercial NA mixture 1, CYP3A4 for $\mathrm{z}=2$ and 4 compounds, GST for $\mathrm{z}=6$ and 10 compounds and MDR for $\mathrm{z}$ $=10$ compound. Gene expression involved in oxidative stress 


\begin{tabular}{|c|c|c|c|c|}
\hline Target genes & Symbol & Foward primer & Reverse primer & $\begin{array}{l}\text { Amplicon } \\
\text { size (bp) }\end{array}$ \\
\hline $\begin{array}{l}\text { APEX nuclease (multifunctional DNA } \\
\text { repair enzyme) }\end{array}$ & APEX & TGACAACGGCACAGCTCCCG & GGCCTCGTCACGCACCCAAT & 199 \\
\hline Catalase & CAT & TGATGTCACACAGGTGCGTA & GTGGGCTCAGTGTTGTTGAG & 195 \\
\hline Cytochrome P450 1A & CYP1A & GATGTCAGTGGCAGCTTTGA & TCCTGGTCATCATGGCTGTA & 104 \\
\hline Cytochrome P450 3A & CYP3A & TACATGCCATTTGGGGCGGGG & ACGGGCCTCCAGCCTCAGTTT & 195 \\
\hline Estradiol receptor $\beta 2$ & ER & CTGACCCCAGAACAGCTGATC & TCGGCCAGGTTGGTAAGTG & 125 \\
\hline $\begin{array}{l}\text { growth arrest and DNA-damage- } \\
\text { inducible, alpha }\end{array}$ & GADD45 & CGAGGCAGCCAAGTCGCTCA & CTCGCAGCAGAACGCCTGGA & 130 \\
\hline Glyceraldehyde 3P dehydrogenase & GAPDH & CCAACCAAACGCTACCGAAC & CCAGATTCCATCTCAССTT & 173 \\
\hline Glutathion-S-Transferase-P & GST & ATTTTGGGACGGGCTGACA & CCTGGTGCTCTGCTCCAGTT & 81 \\
\hline DNA ligase & Ligase & TGGTGCGATTTTGAAGTGTG & GGTCCTGTGTCCTTGTGGTT & 147 \\
\hline 8-oxoguanine DNA glycosylase & OGG & GGCGGGCAATGGGCAGAAGA & CCGAGTGTGCCCAACCAGCA & 101 \\
\hline proliferating cell nuclear antigen & PCNA & ACAACGCAGACACACTCGCCC & GGGCAAACTCCCCCGATGGC & 156 \\
\hline P-glycoprotein (Abcb1) & pGP & ACGTGCGCTCCCTGAACGTG & GCGTTGGCCTCCCTAGCAGC & 157 \\
\hline $\begin{array}{l}\text { Superoxyde dismutase }(\mathrm{Cu} / \mathrm{Zn} \\
\text { cytosolic) }\end{array}$ & SOD & TGGTCCTGTGAAGCTGATTG & TTGTCAGCTCCTGCAGTCAC & 201 \\
\hline uracil-DNA glycosylase & UNG & TGTCTACCCACССССТCAGCA & CCGTGATATGGGTCCTGGCCG & 96 \\
\hline Vitellogenin & Vtg & AGCCCATCCACGAACTTGCTGTT & AGGGCCAAAACTGCATCAGCCT & 190 \\
\hline \multicolumn{5}{|l|}{ Reference genes } \\
\hline Elongation factor I $\alpha$ & EFI $\alpha$ & GAATCGGCTATGCCTGGTGAC & GGATGATGACCTGAGCGGTG & 141 \\
\hline RNA polymerase I & RPL & ACTATGGCTGTCGAGAAGGTGCT & TGTACTCGAACAGTCGTGGGTCA & 120 \\
\hline Prolylpeptidyl isomerase I & PPIA & CATCCCAGGTTTCATGTGC & CCGTTCAGCCAGTCAGTGTT & 203 \\
\hline $\begin{array}{l}\text { Hypoxanthine phosphoribosyl } \\
\text { transferase I }\end{array}$ & HPRT & CCGCCTCAAGAGCTACTGTAAT & GTCTGGAACCTCAAACCCTATG & 255 \\
\hline
\end{tabular}

Table 4: Physico-chemical properties of OSPW and surface waters of the Athabasca River

\begin{tabular}{|c|c|c|c|c|c|c|c|}
\hline & $\begin{array}{c}\mathrm{pH} \\
\text { (units) }\end{array}$ & $\begin{array}{l}\text { Conductivity } \\
(\mu \mathrm{s} / \mathrm{cm})\end{array}$ & $\begin{array}{l}\text { Suspended matter } \\
(\mathrm{mg} / \mathrm{L})\end{array}$ & $\begin{array}{c}\text { DOC } \\
(\mathrm{mg} / \mathrm{L})\end{array}$ & $\begin{array}{c}\text { Light PAHs } \\
\text { (phenanthrene) }\end{array}$ & Total PAHs & Light/total \\
\hline Upstream & 8.8 & 291.6 & 10.4 & 4 & 159 & 350 & $47 \%$ \\
\hline $\begin{array}{l}\text { OS development } \\
\text { area }\end{array}$ & 8.8 & 280.3 & 20.9 & 12 & 217 & 473 & $47 \%$ \\
\hline OSPW & 9 & 2200 & 360 & 55 & 3300 & 4600 & $72 \%$ \\
\hline $\begin{array}{l}\text { Muskeg River } \\
\text { confluence }\end{array}$ & 8.7 & 413.7 & 16.3 & 8 & 125 & 375 & $33 \%$ \\
\hline $\begin{array}{l}\text { Ells River } \\
\text { confluence }\end{array}$ & 8.6 & 268.8 & 23.1 & 7 & 208 & 411 & $51 \%$ \\
\hline NA Mix 1 & --- & --- & --- & & 6724 & 7371 & $91 \%$ \\
\hline NA Mix 2 & --- & --- & --- & & 1483 & 2043 & $72 \%$ \\
\hline
\end{tabular}

revealed upregulation for most NA compounds but was down regulated with CAT for $\mathrm{z}=2,4$ and 6 compounds and OGG for the $\mathrm{z}=0$ compound. The most marked changes were observed for CAT with $\mathrm{z}=8$ compound, and for OGG with $\mathrm{z}=2$ compound and commercial NA mix 2. SOD gene expression responded with the least intensity; responding only with $\mathrm{z}=0, \mathrm{z}=4, \mathrm{z}=10$ compounds and the 2 commercial NA mixtures. Genes involved in Genotoxicity (mostly DNA repair activity) were generally up regulated, with the exception of $U N G$ for $z=0, z=2$ and $z=$ 10 compounds. The most marked responses were obtained for UNG with $\mathrm{z}=8$ compound, APEX with $\mathrm{z}=6$ compound and the 2 commercial NAs mixtures, LIG with $\mathrm{z}=2, \mathrm{z}=4, \mathrm{z}=8$ compounds and commercial NA mixture 2. The strongest response for GADD45 gene expression was observed for commercial NA mixture 1. Genes involved in endocrine disruption were generally up regulated; however, down regulation occurred for ER2 with 


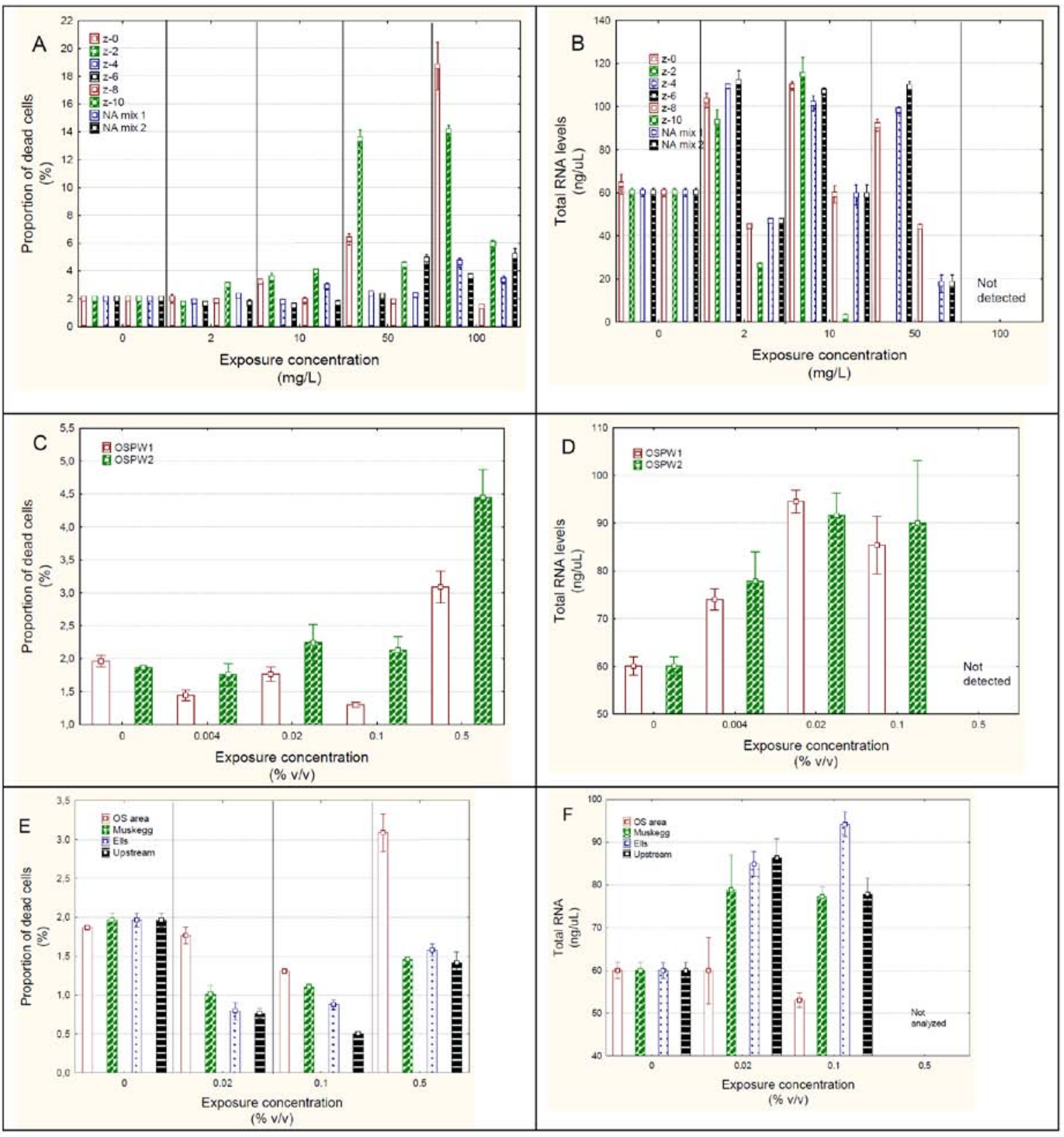

Figure 1: Loss in cell viability and total RNA levels in rainbow trout hepatocytes. Cell viability and total RNA levels in hepatocytes are shown A and $\mathrm{B}$, respectively, for exposure to selected NAs, in C and D, respectively, for OSPW, and in E and F, respectively, for river water.

$\mathrm{z}=0$ and $\mathrm{z}=4$ compounds and for VTG with $\mathrm{z}=0$ compound. The marker gene for anaerobic glycolysis (GAPDH) was significantly up regulated with almost all NA-like single compounds and the mixtures, except for $\mathrm{z}=6$ compound, for which significantly lower levels were observed. The strongest responses for GAPDH were found with $\mathrm{z}=8$ and $\mathrm{z}=10$ compounds. The gene marker for cellular proliferation was generally down regulated; however, $\mathrm{z}=10 \mathrm{NA}$ and commercial NA mixture 2 produced no changes, and commercial NA mixture 1 induced gene expression of PCNA somewhat (1.3 times the control).
The effect of OSPW and surface water extracts collected upstream and downstream from the OS development area on gene expression was also determined (Table 5). Genes involved in biotransformation were up regulated in most cases, with the exception of GST gene expression, which was always down regulated. The upstream site, located in a high density area of OS deposits(10 km north of Fort McMurray),did not produce changes in all tested genes involved in biotransformation. CYP1A1 gene expression was significantly induced for one of the 2 OSPW samples and somewhat down regulated in the OS extraction 


\begin{tabular}{|c|c|c|c|c|c|c|c|c|}
\hline Gene category & Gene id & $\mathrm{z}=0$ & $\mathrm{z}=2$ & $z=4$ & $z=6$ & $z=8$ & $z=10$ & $\begin{array}{l}\text { NA } \\
\text { Mix } 1 \\
\text { Mix } 2\end{array}$ \\
\hline \multirow[t]{4}{*}{$\begin{array}{l}\text { Xenobiotic } \\
\text { biotransformation }\end{array}$} & CYP1A1 & $1.7(10 \mathrm{mg} / \mathrm{L})^{1}$ & $\mathrm{~ns}^{2}$ & $\begin{array}{l}1.9(50 \\
\mathrm{mg} / \mathrm{L})\end{array}$ & $1.5(2 \mathrm{mg} / \mathrm{L})$ & ns & $3.4(2 \mathrm{mg} / \mathrm{L})$ & $\begin{array}{l}2.8(2 \mathrm{mg} / \mathrm{L}) \\
1.5(2 \mathrm{mg} / \mathrm{L})\end{array}$ \\
\hline & CYP3A4 & $1.6(10 \mathrm{mg} / \mathrm{L})$ & $2(2 \mathrm{mg} / \mathrm{L})$ & $1.7(2 \mathrm{mg} / \mathrm{L})$ & $\begin{array}{l}1.3(2 \mathrm{mg} / \mathrm{L}) \\
0.65\end{array}$ & $1.4(2 \mathrm{mg} / \mathrm{L})$ & $\begin{array}{l}0.56(2 \\
\mathrm{mg} / \mathrm{L})\end{array}$ & $\begin{array}{l}1.9(2 \mathrm{mg} / \mathrm{L}) \\
1.6(2 \mathrm{mg} / \mathrm{L})\end{array}$ \\
\hline & GST & $0.45(10 \mathrm{mg} / \mathrm{L})$ & $0.8(2 \mathrm{mg} / \mathrm{L})$ & $0.7(2 \mathrm{mg} / \mathrm{L})$ & $0.48(2 \mathrm{mg} / \mathrm{L})$ & $\begin{array}{l}0.5(10 \\
\mathrm{mg} / \mathrm{L})\end{array}$ & $\begin{array}{l}0.44(2 \\
\mathrm{mg} / \mathrm{L})\end{array}$ & $\begin{array}{l}\text { ns } \\
\text { ns }\end{array}$ \\
\hline & PGP (MDR) & $3(10 \mathrm{mg} / \mathrm{L}) 0.3$ & $4(10 \mathrm{mg} / \mathrm{L})$ & $\begin{array}{l}1.8(50 \\
\mathrm{mg} / \mathrm{L})\end{array}$ & $1.3(50 \mathrm{mg} / \mathrm{L})$ & $\begin{array}{l}4.4(10 \\
\mathrm{mg} / \mathrm{L})\end{array}$ & $7(2 \mathrm{mg} / \mathrm{L})$ & $\begin{array}{l}1.5(2 \mathrm{mg} / \mathrm{L}) \\
1.7(10 \\
\mathrm{mg} / \mathrm{L})\end{array}$ \\
\hline \multirow[t]{3}{*}{ Oxidative stress } & SOD & $2.2(50 \mathrm{mg} / \mathrm{L})$ & ns & ns & $1.4(2 \mathrm{mg} / \mathrm{L})$ & ns & $\begin{array}{l}1.5(10 \\
\mathrm{mg} / \mathrm{L})\end{array}$ & $\begin{array}{l}1.3(2 \mathrm{mg} / \mathrm{L}) \\
\mathrm{ns}\end{array}$ \\
\hline & CAT & $1.5(50 \mathrm{mg} / \mathrm{L})$ & $0.5(2 \mathrm{mg} / \mathrm{L})$ & $\begin{array}{l}0.6(50 \\
\mathrm{mg} / \mathrm{L})\end{array}$ & $0.75(10 \mathrm{mg} / \mathrm{L})$ & $1.7(2 \mathrm{mg} / \mathrm{L})$ & $1.9(2 \mathrm{mg} / \mathrm{L})$ & $\begin{array}{l}1.7(2 \mathrm{mg} / \mathrm{L}) \\
1.2(2 \mathrm{mg} / \mathrm{L})\end{array}$ \\
\hline & OGG & $0.5(50 \mathrm{mg} / \mathrm{L})$ & $1.4(2 \mathrm{mg} / \mathrm{L})$ & $1.4(2 \mathrm{mg} / \mathrm{L})$ & $1.5(2 \mathrm{mg} / \mathrm{L})$ & $1.4(2 \mathrm{mg} / \mathrm{L})$ & ns & $\begin{array}{l}2.2(2 \mathrm{mg} / \mathrm{L}) \\
\mathbf{1 . 9}(\mathbf{2} \mathrm{mg} / \mathrm{L})\end{array}$ \\
\hline \multirow[t]{4}{*}{ Genotoxicity } & UNG & $0.7(2 \mathrm{mg} / \mathrm{L})$ & $0.45(10 \mathrm{mg} / \mathrm{L})$ & $1.4(2 \mathrm{mg} / \mathrm{L})$ & ns & $1.5(2 \mathrm{mg} / \mathrm{L})$ & $0.7(10 \mathrm{mg} / \mathrm{L})$ & $\begin{array}{l}1.6(2 \mathrm{mg} / \mathrm{L}) \\
2(10 \mathrm{mg} / \mathrm{L})\end{array}$ \\
\hline & APEX & $1.8(10 \mathrm{mg} / \mathrm{L})$ & $1.7(10 \mathrm{mg} / \mathrm{L})$ & $2(10 \mathrm{mg} / \mathrm{L})$ & $2(2 \mathrm{mg} / \mathrm{L})$ & $\begin{array}{l}2.7(10 \\
\mathrm{mg} / \mathrm{L})\end{array}$ & $1.3(2 \mathrm{mg} / \mathrm{L})$ & $\begin{array}{l}3.4(2 \mathrm{mg} / \mathrm{L}) \\
3.2(2 \mathrm{mg} / \mathrm{L})\end{array}$ \\
\hline & Ligase & $1.6(10 \mathrm{mg} / \mathrm{L})$ & $1.6(2 \mathrm{mg} / \mathrm{L})$ & $1.5(2 \mathrm{mg} / \mathrm{L})$ & $1.5(2 \mathrm{mg} / \mathrm{L})$ & $1.7(2 \mathrm{mg} / \mathrm{L})$ & ns & $\begin{array}{l}2.2(2 \mathrm{mg} / \mathrm{L}) \\
2(2 \mathrm{mg} / \mathrm{L})\end{array}$ \\
\hline & GADD45 & $2(10 \mathrm{mg} / \mathrm{L})$ & $1.7(10 \mathrm{mg} / \mathrm{L})$ & ns & $2.2(50 \mathrm{mg} / \mathrm{L})$ & $\begin{array}{l}2.4(10 \\
\mathrm{mg} / \mathrm{L})\end{array}$ & $2(2 \mathrm{mg} / \mathrm{L})$ & $\begin{array}{l}2.4(2 \mathbf{~ m g} / \mathrm{L}) \\
1.7(10 \\
\mathrm{mg} / \mathrm{L})\end{array}$ \\
\hline \multirow[t]{2}{*}{ Estrogenicity } & ER2 & $0.4(2 \mathrm{mg} / \mathrm{L})^{3}$ & ns & $\begin{array}{l}1.8(10 \\
\mathrm{mg} / \mathrm{L})\end{array}$ & $0.1(2 \mathrm{mg} / \mathrm{L})$ & $2(10 \mathrm{mg} / \mathrm{L})$ & $\begin{array}{l}1.4(10 \\
\mathrm{mg} / \mathrm{L})\end{array}$ & $\begin{array}{l}1.9(2 \mathrm{mg} / \mathrm{L}) \\
\mathrm{ns}\end{array}$ \\
\hline & VTG & $0.4(2 \mathrm{mg} / \mathrm{L})$ & $4.8(10 \mathrm{mg} / \mathrm{L})$ & ns & $1.7(50 \mathrm{mg} / \mathrm{L})$ & $\begin{array}{l}1.7(10 \\
\mathrm{mg} / \mathrm{L})\end{array}$ & ns & $\begin{array}{l}3.6(10 \\
\mathrm{mg} / \mathrm{L}) \\
1.9(10 \\
\mathrm{mg} / \mathrm{L})\end{array}$ \\
\hline \multirow[t]{2}{*}{ Other } & GADPH & $1.3(50 \mathrm{mg} / \mathrm{L})$ & $1.3(10 \mathrm{mg} / \mathrm{L})$ & $\begin{array}{l}1.6(10 \\
\mathrm{mg} / \mathrm{L})\end{array}$ & $\begin{array}{l}0.58(10 \\
\mathrm{mg} / \mathrm{L})\end{array}$ & $1.5(2 \mathrm{mg} / \mathrm{L})$ & $2.6(2 \mathrm{mg} / \mathrm{L})$ & $\begin{array}{l}1.8(2 \mathrm{mg} / \mathrm{L}) \\
1.4(2 \mathrm{mg} / \mathrm{L})\end{array}$ \\
\hline & PCNA & $0.4(2 \mathrm{mg} / \mathrm{L})$ & $0.5(2 \mathrm{mg} / \mathrm{L})$ & $0.6(2 \mathrm{mg} / \mathrm{L})$ & $0.6(2 \mathrm{mg} / \mathrm{L})$ & $\begin{array}{l}0.66(2 \\
\mathrm{mg} / \mathrm{L})\end{array}$ & ns & $\begin{array}{l}1.3(2 \mathrm{mg} / \mathrm{L}) \\
\mathrm{Ns}\end{array}$ \\
\hline
\end{tabular}

1. The data are expressed as the significant response factor (normalized to controls) at the lowest concentration. Response factors $<1$ are decreased relative to the controls; the concentration is in parentheses.

2. Ns: not significant

3. The 3 most sensitive endpoints are highlighted in bold. The endpoints are calculated based on the ratio of the fold change/concentration in mg/L.

area; no effects were observed for the other downstream sites. CYP3A4 was strongly induced by both OSPW samples as well as at the confluence of Ells River but with less intensity. GST gene expression was consistently depressed in OSPW1 and at the confluence of both the Muskeg and Ells rivers. The MDR transcript levels were significantly higher in both OSPW1 and OSPW2 and at the confluence of both the Muskeg and Ells rivers. Genes involved in oxidative stress were generally induced, although some showed a decrease (OSPW1 for SOD). CAT and OGG gene expression was increased at the upstream site but the increase was less marked based on the fold change/ concentration ratio. The strongest responses were observed for the OGG gene as follows: for both OSPW samples, the OS downstream area and at the confluence of Ells River. Strong responses were also observed for CAT at the Muskeg and Ells rivers. Genes involved in DNA repair or Genotoxicity were also examined. The upstream site showed a small increase in DNA repair activity based on APEX and GADD45 gene expression but the responses occurred at higher concentrations compared to those at downstream sites. UNG gene expression was induced by both OSPW samples and by all the other downstream sites, whereas the upstream site did not produce any significant changes. The same was observed for LIG gene expression but the responses were stronger than for UNG. APEX gene expression was strongly induced in both OSPW samples at the lowest concentration tested, but the gene was induced at the upstream site as well. The Estrogenicity evaluation based on ER2 and VTG gene expression revealed some upstream/ downstream trends. ER2 transcript levels were significantly higher in OSPW2 and at all downstream sites, but there was no effect at the upstream site. VTG gene expression was only induced in OSPW2, which suggests that OS tailings have modest estrogenic 


\begin{tabular}{|c|c|c|c|c|c|c|}
\hline Gene category & Gene ID & $\begin{array}{l}\text { OSPW1 } \\
\text { OSPW2 }\end{array}$ & OS area & $\begin{array}{l}\text { Muskeg River } \\
\text { confluence }\end{array}$ & $\begin{array}{l}\text { Ells River } \\
\text { confluence }\end{array}$ & Upstream \\
\hline \multirow[t]{4}{*}{$\begin{array}{l}\text { Xenobiotic } \\
\text { biotransformation }\end{array}$} & CYP1A1 & $\begin{array}{l}\text { ns } \\
1.5(0.02 \%)\end{array}$ & $0.7(0.1 \%)$ & ns & ns & ns \\
\hline & CYP3A4 & $\begin{array}{l}\mathbf{1 . 8}(\mathbf{0 . 0 0 4 \% )} \\
1.5(0.02 \%)\end{array}$ & ns & ns & $1.3(0.02 \%)$ & ns \\
\hline & GST & $\begin{array}{l}\text { ns } \\
0.6(0.1 \%)\end{array}$ & ns & $0.65(0.02 \%)$ & $0.7(0.1 \%)$ & ns \\
\hline & PGP (MDR) & $\begin{array}{l}1.6(0.1 \%) \\
\mathbf{2 . 1}(\mathbf{0 . 0 2 \% )}\end{array}$ & ns & $1.5(0.02 \%)$ & $1.3(0.1 \%)$ & ns \\
\hline \multirow[t]{3}{*}{ Oxidative stress } & SOD & $\begin{array}{l}0.7(0.004 \%) \\
1.2(0.02 \%)\end{array}$ & ns & ns & ns & ns \\
\hline & CAT & $\begin{array}{l}1.4(0.1 \%) \\
\text { ns }\end{array}$ & ns & $1.6(0.02 \%)$ & $1.6(0.02 \%)$ & $2(0.1 \%)$ \\
\hline & OGG & $\begin{array}{l}1.6(0.004 \%) \\
1.5(0.004 \%)\end{array}$ & $1.4(0.02 \%)$ & $1.5(0.02 \%)$ & $1.6(0.02 \%)$ & $1.9(0.1 \%)$ \\
\hline \multirow[t]{4}{*}{ Genotoxicity } & UNG & $\begin{array}{l}1.5(0.004 \%) \\
1.7(0.02 \%)\end{array}$ & $1.7(0.02 \%)$ & $1.8(0.1 \%)$ & $1.2(0.1 \%) 12$ & ns \\
\hline & APEX & $\begin{array}{l}2.1(0.004 \%) \\
2.5(0.004 \%)\end{array}$ & ns & $1.7(0.02 \%)$ & $2.2(0.02 \%)$ & $1.6(0.02 \%)$ \\
\hline & Ligase & $\begin{array}{l}2.8(0.004 \%) \\
1.4(0.004 \%)\end{array}$ & $1.2(0.02 \%)$ & $1.4(0.02 \%)$ & $1.5(0.02 \%)$ & ns \\
\hline & GADD45 & $\begin{array}{l}\text { ns } \\
0.8(0.004 \%)\end{array}$ & $0.6(0.1 \%)$ & ns & $0.7(0.1 \%)$ & $0.7(0.02 \%)$ \\
\hline \multirow[t]{2}{*}{ Estrogenicity } & ER2 & $\begin{array}{l}\text { ns } \\
1.6(0.02 \%)\end{array}$ & $2(0.02 \%)$ & $1.6(0.02 \%)$ & $1.3(0.1 \%)$ & ns \\
\hline & VTG & $\begin{array}{l}\text { ns } \\
18(0.1 \%)\end{array}$ & ns & ns & ns & ns \\
\hline \multirow[t]{2}{*}{ Other } & GADPH & $\begin{array}{l}1.47(0.004 \%) \\
1.5(0.02 \%)\end{array}$ & $1.9(0.1 \%)$ & $1.3(0.02 \%)$ & $1.3(0.02 \%)$ & $1.4(0.1 \%)$ \\
\hline & PCNA & $\begin{array}{l}1.2(0.02 \%) \\
1.5(0.02 \%)\end{array}$ & ns & ns & $1.2(0.1 \%)$ & Ns \\
\hline
\end{tabular}

1. The data are expressed as the significant response factor (normalized to controls) at the lowest concentration. Response factors $<1$ are decreased relative to the controls; the concentration is in parentheses.

2. Ns: not significant

3. The 3 most sensitive endpoints are highlighted in bold. The endpoints are calculated based on the ratio of the fold change/concentration in $\%$ $\mathrm{v} / \mathrm{v}$.

activity. The marker gene for anaerobic glycolysis was induced to a significantly greater extent for all sites, including the upstream site. However, the responses were stronger (i.e., higher response relative to the controls at lower concentrations) for the OSPW1, OSPW2 and OS extraction area sites. The gene marker for cell proliferation showed no clear trends, although some induction was observed for both OSPW sites/ samples. Correlation analysis revealed that cell viability was significantly correlated with CAT $(r=-0.38)$, GST $(r=-0.43)$, SOD $(r=-0.22)$, GAPDH $(r=-0.3)$, PCNA $(r=-0.32)$, CYP3A4 $(r=-0.41)$, UNG $(r=-0.37)$, GADD45 $(r=0.25)$, VTG $(r=0.29)$, ER2 $(r=-0.22)$, SOD $(r=0.21)$ and MDR $(r=0.54)$, suggesting that these genes were associated with a cytotoxic effect. The analysis also revealed that the changes in total RNA levels were correlated with CAT $(r=-0.36)$, GST ( $r=$ -0.52), SOD ( $r=-0.22)$, GADPH $(r=-0.4)$, PCNA $(r=-0.3)$, UNG $(r=-0.27)$ and ER2 $(r=-0.37)$.We also performed a canonical analysis of gene expression data to identify the gene groups (biotransformation, Genotoxicity, oxidative stress, endocrine disruption, anaerobic glycolysis and cell proliferation) linked to changes in Cytotoxicity (cell viability and total RNA levels) (Figure 2). The genes involved in biotransformation, oxidative stress and Genotoxicity were found to be highly correlated with Cytotoxicity. Hence, these groups point to possible adverse toxic outcomes for OSPW and OS development area contaminants.

A classification and regression tree (CART) analysis was performed on the gene expression and Cytotoxicity data to get an global view about the cytotoxic properties of individual compounds, commercial NA mixtures, OSPW and surface water samples towards rainbow trout hepatocytes (Figure 3). The analysis revealed 4 distinct clusters based on a number of properties (rules) related to gene expression and Cytotoxicity data. The first cluster consists of the control and upstream surface water extracts, which were classified based on the following rules or observations: no/low cell mortality and LIG gene expression levels at first, followed by UNG levels > 1.1 and GADD45 levels $<0.7$, then the sample belongs to the second sub- 
cluster, and is still considered upstream; however, if GADD45 is $>0.7$, the sample is now considered downstream water. Downstream waters are characterized by increased expression of DNA repair genes such as UNG, GADD45, and LIG. When LIG gene expression reaches $>1.7$ fold, the sample belongs to the next (third) cluster, which contains NA mixtures 1 and 2. NA mixtures are characterized by high LIG gene expression levels ( $>1.7$ fold). OSPW 1 and 2 are found in the 4th cluster, which is characterized by high Cytotoxicity ( $>1.3$ fold relative to the controls). OSPW samples are characterized by high levels of CYP1A1 and PCNA gene expression for OSPW1. OSPW2 is characterized by increased CYP3A4 expression and low GST values (at least $>0.6$ ). The individual NAs were distributed within the fourth cluster (OSPW), with the exception of $\mathrm{z}=8$, which was located in the third NA mixture cluster. No clear pattern of gene expression was found for the individual NAs, but marked changes in CYP1A1 ( $>2.8$ fold) and CYP3A4 ( $>2$ fold) and GADD45 ( $>1.1$ fold) were found for $\mathrm{z}$ $=10, \mathrm{z}=2$ and $\mathrm{z}=8$ compounds. The most important biomarkers ( $<80 \%$ relative importance) permitting classification of the various samples were PCNA, CYP3A4, GADD45, LIG and CYP1A1. These biomarkers were strongly associated with Cytotoxicity responses, with the exception of PCNA.

\section{Discussion}

Analysis OSPW, NA mixtures and surface waters revealed that they contained significant amounts of PAHs. The proportion of light PAHs was significantly higher in the OSPW and NAs mixtures, accounting for about $80 \%$ of the total PAHs, compared to $33-51 \%$ in surface water samples. The increase in the proportion of light PAHs paralleled the increases in total suspended solids and dissolved organic carbon contents observed in OSPW compared to surface water samples; hence, these properties could be considered general markers of OSPW contamination. This is in keeping that the Clark extraction procedure liberates low molecular weight hydrocarbons and carboxylic acids (NAs) during the caustic hot water extraction process. Based on these parameters, there was no clear evidence that surface waters were tainted with OSPW or NA mixtures. This is consistent with the finding reported in a previous study, specifically that only groundwater showed evidence of OSPW-

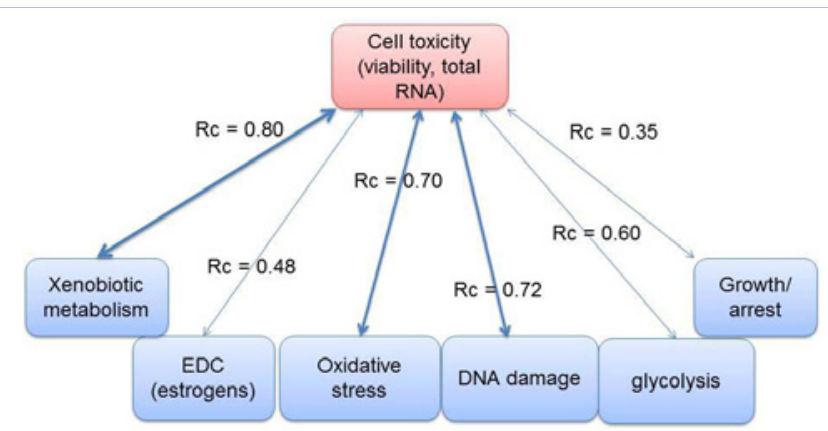

Figure 2: Canonical analysis of gene expression data and cell toxicity Canonical analysis was performed on the gene expression data and cytoxicitydata, based on loss of cell membrane permeability and changes in total RNA levels, in order to identify pathways of toxicity in hepatocytes exposed to various OS-related products.
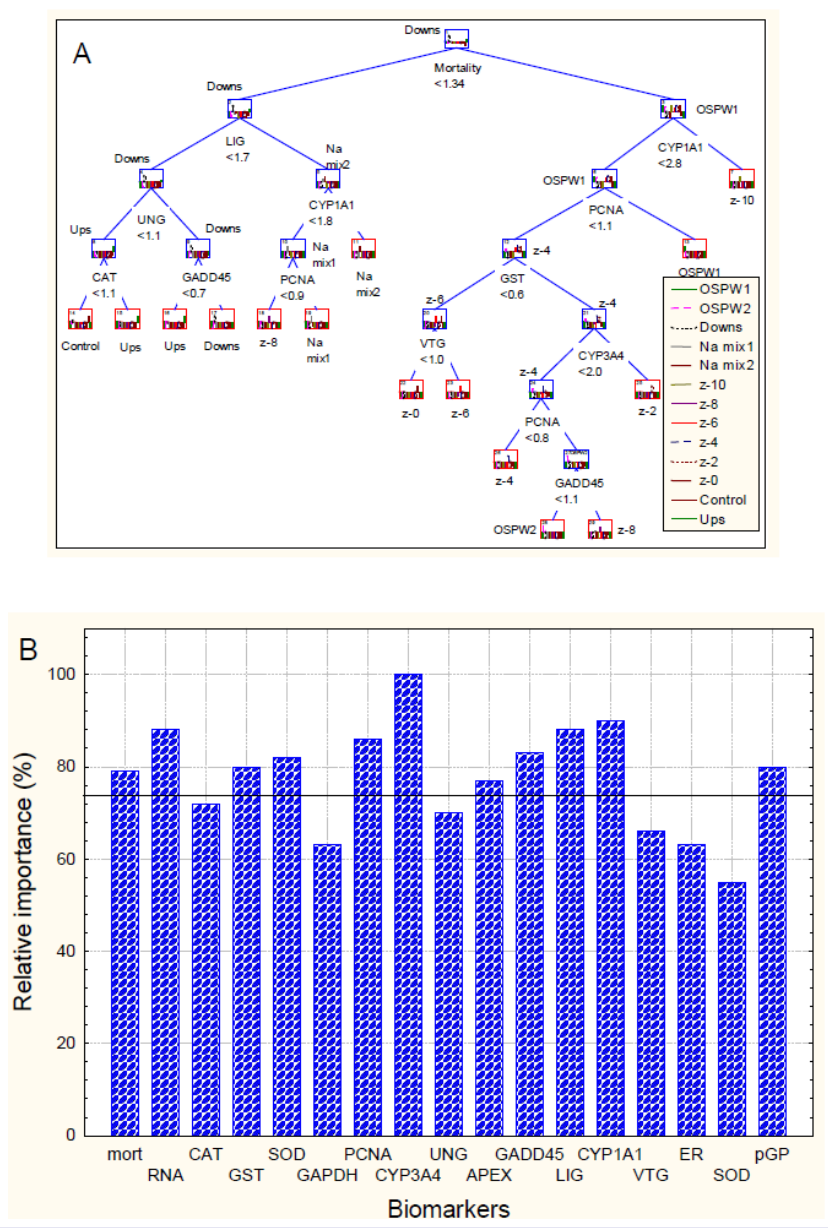

Figure 3: Decision tree classification of OS samples based on gene expression and cell toxicity

Decision tree analysis was performed using the CART algorithm (univariate) to identify the divisions with the best performance. The decision tree and rules for each division are shown in A and the most important biomarkers for sample classification are shown in B. The dashed line in figure $3 \mathrm{~B}$ represents the $75 \%$ threshold.

related contamination [14]. In the present study, CYP3A4 and GST gene expression was up regulated and down regulated, respectively, in hepatocytes exposed to OSPW. Commercial NA mixtures led to increased CYP3A4 gene expression in trout hepatocytes but had no effect on GST gene expression. Increased CYP3A4gene expression, indicative of phase 1 biotransformation of cyclic aliphatic hydrocarbons, was proposed a specific gene marker for OSPW compared to surface waters [12]. No induction inCYP3A4 transcripts in hepatocytes exposed to surface waters, except a small increase (1.3 fold) for the water sample taken at the confluence of Ells River, was detected. A decrease in GST gene expression was observed in previous studies at both gene expression [17] and enzyme activity levels [14]. Decreased GST gene expression was closely associated with OSPW and with surface waters downstream from the OS development area. Although the reason for the decreases in GST activity or gene expression is unclear at present, they seem to be a consistent pattern associated with OS mining activity. 
OPSW Genotoxicity was found in the present study based on the observation that the most marked responses in DNA repair genes were obtained with the two OSPW samples. To the best of our knowledge, [14] were the first to report DNA damage in a study on rainbow trout hepatocytes exposed to OSPW extracts and surface waters. DNA strand breaks in primary cultures of trout hepatocytes exposed to surface waters and OSPW extracts were found to be the most responsive endpoint; however, they offered the least discrimination between "natural" or background levels in the area rich in OS deposits and the area downstream from OS mining activity. This highlights the challenge involved in discriminating between natural releases of OS contaminants and those associated with mining activities in the region. Moreover, marked DNA repair gene expression was also observed for both upstream and downstream surface waters, with a trend of higher responses for the area downstream from the OS mining operations. This is consistent with the relatively high background values of PAHs found in the area rich in OS deposits $[5,13]$. PAHs are known to induce CYP1A1 gene expression and produce DNA damage [22]. High molecular weight (heavy) PAHs were found to be responsible for most of the mutagenic activity. The comet assay was used in rainbow trout hepatocytes to examine the contribution of some NAs (including commercial mixtures), OSPW and OS leachates in terms of mimicking the natural background release of genotoxic compounds [15]. Genotoxicity was observed in all samples from the individual compounds $(\mathrm{z}=6$ to $\mathrm{z}=10)$, commercial NAs, OSPW and OS leachates. However, genotoxic potential was higher for OSPW than for the OS leachates and it was strongly involved oxidative DNA damage. A recent study revealed that diamondoid naphthenic acids caused in vivo DNA damage in the hemocytes and gills of marine mussels [23]. This is keeping with our results and those of the Lacaze, et al. [15] study in which a noradamantane carboxylic acid increased the expression of APEX, LIG and GADD45 genes. Interestingly, the noradamantane carboxylic acid $(\mathrm{z}=6)$ also induced the expression of OGG (DNA repair of oxidized guanine) at lower intensities (1.5 fold at 2 $\mathrm{mg} / \mathrm{L}$ ) than for LIG and APEX, which produced 2-fold (2 mg/ L) and 2.2 -fold $(50 \mathrm{mg} / \mathrm{L})$ responses, respectively. This was also found with the comet assay on trout hepatocytes at much lower concentrations ( $0.2 \mathrm{mg} / \mathrm{L})$ in the Lacaze, et al. study[15].

Recent evidence suggests that some OS products are capable of inducing VTG gene expression in rainbow trout [12]. To the best of our knowledge, this was the first report VTG gene upregulation in trout hepatocytes exposed to OSPW and to surface waters from the OS development area.VTG gene expression was markedly increased in one of the OSPW samples with a response 18 times greater than for the controls. There was no indication of induction in hepatocytes exposed to surface waters. ER2 gene expression was increased for surface waters from sites downstream from the OS development area and for one of the OSPW extracts. As in the case of Genotoxicity responses, these data suggest that endocrine disrupting substances are present in OSPW and in river water in the area with rich OS deposits; however, the intensity of responses seems to vary from year to year. The commercial NA mixtures also induced VTG and ER2 gene expression, further supporting the hypothesis that OSPW-related material is estrogenic to fish. In a previous study, VTG gene expression increased about 30 -fold when hepatocytes were exposed to OPSW, whereas surface waters were $2 \mathrm{X}$ less potent in inducing VTG (i.e., 15-fold increase relative to controls).Exposure to NAs isolated from OSPW and to commercial NA mixtures significantly increased the production of progesterone and estradiol-17 $\beta$ but decreased testosterone levels in H295R cells [24]. This corroborates the present study's findings of increased CYP3A4 gene expression caused by OSPW and commercial NAs mixtures. Indeed, CYP3A4 codes for the corresponding cytochrome P450, which has $6 \beta$-testosterone hydroxylase activity and is involved in the elimination of testosterone [25].In another study with young-of-the-year zebra fish (Danio rerio), exposures to NAs in OSPW and commercial NA mixtures led to the upregulation of aromatase (CYP19b), Er $\alpha$ and VTG gene expression [26]. These changes in gene expression were associated with delays in embryo hatching, which was followed by developmental lesions such as pericardial edema, yolk sac edema and spinal malformation. These results further support the notion that NAs derived from OS can negatively impact endocrine function in fish and can contribute to long-term toxicity of OSPW. Aromatic NAs were found to weakly induce VTG gene expression in zebra fish larvae [27], suggesting that other types of NAs or other compounds found in OSPW contribute towards estrogenicity or produce effects at the steroid metabolism level, as shown above. It appears that NA endocrine-disrupting effects occur across the brain-gonad-liver axis in fathead minnows exposed to untreated and ozone treated OSPW [28]. The abundances of transcripts of estrogen-responsive genes were greater in livers from male fish exposed to untreated OSPW compared to control male fish. However, the opposite effect was found in female fish, which showed a decrease in estrogen-responsive genes in the liver. The same pattern was observed for the gonads. By contrast, in brain tissue, the abundance of transcripts of genes important for synthesis of gonadotropins was greater in both male and female fish exposed to OSPW than in control fish. These results indicate that the endocrine-disrupting effect goes beyond the liver and affects the entire brain-gonad-liver axis.

The reported toxicity of the individual organic compounds in this study is limited to aquatic species. Chemical characterization of commercial NAs revealed that the majority of NAs in commercial mixtures were composed of 1 to 3 rings [29]. These commercial preparations also contain monoaromatic acids and non-acids (both found in the light PAHs fraction), PAHs and sulfur heterocyclic hydrocarbons. Abietic acid $(z=10)$ was found not to influence VTG gene expression, although a small increase in ER2 gene expression is observed at a relatively high concentration of $10 \mathrm{mg} / \mathrm{L}$. It was found that abietic acid in combination with estrogenic compounds contributed to male feminization of the roach [30]. This suggests that some NAs could potentiate the effect of environmental estrogens. Abietic acid was found to cause inhibition in GST gene expression. GST inhibition was also observed in mussels exposed to $3 \mu \mathrm{M}(0.9 \mathrm{mg} / \mathrm{L})$ of abietic acid for up to $24 \mathrm{~h}$ [31]. DNA integrity and oxidative stress in mussel hepatopancreas were respectively decreased and increased in exposed mussels, a finding that parallels the 
present study's 2-fold increase in GADD45 gene expression with increases in SOD and CAT, which is indicative of oxidative stress responses. The Genotoxicity and biotransformation potential of abietic acid was investigated in the eel Anguilla anguilla $L$ $[32,33]$. Low concentrations of abietic acid ( 0.1 to $0.3 \mathrm{mM})$ were found to increase EROD activity (CYP1A1) in eels, which is in line with the observed induction in gene expression of CYP1A1 (3.4 fold relative to the controls). Abietic acid also increased erythrocyte nuclear abnormalities and DNA strands in the liver of exposedeels. Thee resin acid, abietic acid, which originates from the decomposition of plants/trees, may be present in bitumen but it also occurs naturally in the environment, as well as in municipal and pulp mill effluent wastewaters; hence, it is not considered specific to OSPW.

In this study, based on canonical analysis, the genes involved in Xenobiotic biotransformation, oxidative stress and DNA repair activity were strongly related to Cytotoxicity. Exposure to OSPW was shown to alter gene expression of male fathead minnows involved in oxidative stress, oxidative metabolism (which involves biotransformation), apoptosis and immune function [34].In another study, fathead minnow embryos exposed to OSPW hatched prematurely and the embryos exhibited higher incidences of hemorrhage, pericardial edema and malformation of the spine [35]. These embryos had elevated reactive oxygen species with a greater abundance of transcripts for CYP3A, GST, SOD and caspase 9. This suggests that OSPW caused oxidative stress and biotransformation of Xenobiotic s which can lead to mitochondrial dysfunction and apoptosis. Hepatocytes exposed to commercial NA mixtures and OSPW had elevated levels of GAPDH, which is involved in anaerobic glycolysis. This could be a consequence of altered mitochondria in the liver due to increased levels of oxidative stress and biotransformation. It is noteworthy that this marker gene was equally expressed in surface waters downstream from the OS extraction area and at the upstream site, suggesting that OS-rich deposits may contain chemicals that affect the aerobic/ anaerobic balance in cells. However, based on canonical analysis, this endpoint was not as strongly correlated to Cytotoxicity compared to the other gene endpoints, indicating that this effect may not be a major driver of toxicity. Nonetheless, this also raises the possibility that disturbance in aerobic/ anaerobic glycolysis could be a contributing factor to the toxicity of OSPW and NAs.

In conclusion, exposure of rainbow trout hepatocytes to OSrelated products revealed various effects at the gene expression level, including biotransformation, oxidative stress, DNA repair activity, anaerobic glycolysis and growth arrest. It was found that genes involved in biotransformation, oxidative stress and DNA damage (repair) were the most strongly associated $\left(r_{c}\right.$ $\geq 0.70 ; p<0.001$ ) with Cytotoxicity based on cell viability and total RNA levels. Decision tree analysis revealed that upstream waters, downstream waters, commercial NA mixtures and OSPW formed 4 distinct groups based on gene expression data. Some trends related to location upstream/downstream from the OS development area were observed, especially with genes involved in DNA repair (UNG, APEX and LIG) and biotransformation (GST downward expression). Expression of endocrine-disrupting genes was not associated with cell toxicity, VTG was strongly induced by only one of the OSPW samples, and ER2 was expressed in downstream waters. These results collectively suggest that endocrine disruption is not a major effect of exposure to OS-derived products. However, more research is required to determine whether these upstream/downstream trends result from the particular hydrodynamics (confluence of many rivers at downstream sites such as Muskeg and Ells rivers) and mining activities that characterize this region.

\section{Acknowledgements}

The authors wish to thank Joanna Kowalczyk for conducting the biochemical assays in the laboratory. This work was funded by the Oil Sands research and monitoring initiative of Environment and Climate Change Canada.

\section{References}

1. Gosselin P, Hrudey SE, Naeth A, Plourde A, Therrien R, Van Der Kraak G, et al. Environmental and health impacts of Canada's oil sands industry. The Royal Society of Canada/LaSociété Royale du Canada, Ottawa. 2010

2. Frank RA, Roy JW, Bickerton G, Rowland SJ, Headley JV, Scarlett AG, et al. Profiling oilsands mixtures from industrial developments and natural groundwaters for source identification. Environ Sci Technol. 2014;48(5):2660-70. doi: 10.1021/es500131k.

3. Bauer AE, Frank RA, Headley JV, Peru KM, Hewitt LM, Dixon DG. Enhanced characterization of oilsands acid-extractable organics fractions using electrospray ionization-high-resolution mass spectrometry and synchronous fluorescence spectroscopy. Environ. Toxicol.Chem. 2015;34(5):1001-1008. doi: 10.1002/etc.2896.

4. Puttaswamy $\mathrm{N}$, Liber $\mathrm{K}$. Influence of inorganic anions on metals release from oil sands coke and on toxicity of nickel and vanadium to Ceriodaphniadubia. Chemosphere. 2012;86(5):521-9. doi: 10.1016/j. chemosphere.2011.10.018.

5. Kelly EN, Short JW, Schindler DW, Hodson PV, Ma M, Kwan AK, et al. Oil sands development contributes polycyclic aromatic compounds to the Athabasca River and its tributaries. Proc Natl Acad Sci U S A. 2009;106(52):22346-51. doi: 10.1073/pnas.0912050106.

6. Kelly EN, Short JW, Schindler DW, Hodson PV, Ma M, Kwan AK, et al. Oil sands development contributes elements toxic at low concentrations to the Athabasca River and its tributaries. Proc Natl Acad Sci U S A. 2009;106(52):22346-51. doi: 10.1073/pnas.0912050106.

7. Martin JW, Han X, Peru KM, Headley JV. Comparison of high- and lowresolution electrospray ionization mass spectrometry for the analysis of naphthenic acid mixtures in oil sands process water. Rapid Commun Mass Spectrom. 2008;22(12):1919-24. doi: 10.1002/rcm.3570.

8. Holowenko FM, MacKinnon MD, Fedorak PM. Characterization of naphthenic acids in oil sands wastewaters by gas chromatographymass spectrometry. Water Res. 2002;36(11):2843-55.

9. Hagen MO, Katzenback BA, Islam MD, Gamal El-Din M, Belosevic M.The analysis of goldfish (Carassiusauratus L.) innate immune responses after acute and subchronic exposures to oilsands process-affected water. Toxicol Sci. 2014;138(1):59-68. doi: 10.1093/toxsci/kft272.

10. Kavanagh RJ, Frank RA, Solomon KR, Van Der Kraak G. Reproductive and health assessment of fathead minnows (Pimephalespromelas) 
inhabiting a pond containing oilsands process-affected water. Aquat Toxicol. 2013;130-131:201-9. doi: 10.1016/j.aquatox.2013.01.007.

11. Arens CJ, Hogan NS, Kavanagh RJ, Mercer AG, Kraak GJ, van den Heuvel MR. Sublethal effects of aged oilsands-affected water on white sucker (Catostomuscommersonii). Environ Toxicol Chem. 2015;34(3):589-99. doi: 10.1002 /etc.2845.

12. Gagné F, Douville M, André C, Debenest T, Talbot A, Sherry J, et al Differential changes in gene expression in rainbow trout hepatocytes exposed to extracts of oil sands process-affected water and the Athabasca River. Comp Biochem Physiol C Toxicol Pharmacol. 2012;155(4):551-9. doi: 10.1016/j.cbpc.2012.01.004.

13. Casini S, Marsili L, Fossi MC, Mori G, Bucalossi D, Porcelloni S, et al. Use of biomarkers to investigate toxicological effects of produced water treated with conventional and innovative methods. Mar Environ Res. 2006;62 Suppl:S347-51. doi: 10.1016/j.marenvres.2006.04.060.

14. Gagné F, André C, Douville M, Talbot A, Parrott J, McMaster M, et al. An examination of the toxic properties of water extracts in the vicinity of an oil sand extraction site. J Environ Monit. 2011;13(11):3075-86. doi: 10.1039/c1em10591d.

15. Lacaze E, Devaux A, Bruneau A, Bony S, Sherry J, Gagné F. Genotoxic potential of several naphthenic acids and a synthetic oil sands process affected water in rainbow trout (Oncorhynchus mykiss). Aquat Toxicol. 2014;152:291-9. doi: 10.1016/j.aquatox.2014.04.019.

16. Alharbi HA, Saunders DM, Al-Mousa A, Alcorn J, Pereira AS, Martin JW, et al. Inhibition of ABC transport proteins by oilsands process affected water. Aquat Toxicol. 2016;170:81-8. doi: 10.1016/j. aquatox.2015.11.013.

17. Gagné F, André C, Turcotte P, Gagnon C, Sherry J, Talbot A. A comparative toxicogenomic investigation of oil sand water and processed water in rainbow trout hepatocytes. Arch Environ Contam Toxicol. 2013;65(2):309-23. doi: 10.1007/s00244-013-9888-2.

18. Debenest T, Turcotte P, Gagné F, Gagnon C, Blaise C. Ecotoxicological impacts of effluents generated by oil sands bitumen extraction and oil sands lixiviation on Pseudokirchneriellasubcapitata. Aquat Toxicol. 2012;112-113:83-91. doi: 10.1016/j.aquatox.2012.01.021.

19. Baksi SM, Frazier JM. Isolated fish hepatocytes-Model systems for toxicology research. Aquat.Toxicol. 1990;16(4):229-256.

20. Klaunig JE, Ruch RJ, Goldblatt PJ. Trout hepatocyte culture: Isolation and primary culture. In Vitro Cell Dev Biol. 1985;21(4):221-8.

21. Andersen CL, Jensen JL, Ørntoft TF. Normalization of real-time quantitative reverse transcription-PCR data: a model-based variance estimation approach to identify genes suited for normalization, applied to bladder and colon cancer data sets. Cancer Res. 2004;64(15):524550. doi: 10.1158/0008-5472.CAN-04-0496.

22. Marvin CH, Lundrigan JA, McCarry BE, Bryant DW. Determination and genotoxicity of high molecular mass polycyclic aromatic hydrocarbons isolated from coal-tar-contaminated sediment. Environ. Toxicol. Chem. 1995;14(12):2059-2066.

23. Dissanayake A, Scarlett AG, Jha AN. Diamondoid naphthenic acids cause in vivo genetic damage in gills and haemocytes of marine mussels. Environ Sci Pollut Res Int. 2016;23(7):7060-6. doi: 10.1007/ s11356-016-6268-2.

24. Wang J, Cao X, Sun J, Huang Y, Tang X. Disruption of endocrine function in H295R cell in vitro and in zebrafish in vivo by naphthenic acids. J Hazard Mater. 2015;299:1-9. doi: 10.1016/j.jhazmat.2015.06.004.

25. Yamazaki H, Shimada T. Progesterone and testosterone hydroxylation by cytochromes P450 2C19, 2C9, and 3A4 in human liver microsomes. Arch Biochem Biophys. 1997;346(1):161-9. doi: 10.1006/ abbi.1997.0302.

26. Wang J, Cao X, Huang Y, Tang X. Developmental toxicity and endocrine disruption of naphthenic acids on the early life stage of zebrafish (Danio rerio). J Appl Toxicol. 2015;35(12):1493-501. doi: 10.1002/ jat.3166.

27. Reinardy HC1, Scarlett AG, Henry TB, West CE, Hewitt LM, Frank RA, et al. Aromatic naphthenic acids in oil sands process-affected water, resolved by GCxGC-MS, only weakly induce the gene for vitellogenin production in zebrafish (Danio rerio) larvae. Environ Sci Technol. 2013;47(12):6614-20. doi: 10.1021/es304799m.

28. He Y, Wiseman SB, Wang N, Perez-Estrada LA, El-Din MG, Martin JW, et al. Transcriptional responses of the brain-gonad-liver axis of fathead minnows exposed to untreated and ozone-treated oil sands process-affected water. Environ Sci Technol. 2012;46(17):9701-8. doi: 10.1021/es3019258.

29. Swigert JP, Lee C, Wong DC, White R, Scarlett AG, West CE, et al. Aquatic hazard assessment of a commercial sample of naphthenic acids. Chemosphere. 2015;124:1-9. doi: 10.1016/j. chemosphere.2014.10.052.

30. Lange A, Sebire M, Rostkowski P, Mizutani T, Miyagawa S, Iguchi T, et al. Environmental chemicals active as human antiandrogens do not activate a stickleback androgen receptor but enhance a feminising effect of oestrogen in roach. Aquat Toxicol. 2015;168:48-59. doi: 10.1016/j.aquatox.2015.09.014.

31. Gravato C, Oliveira M, Santos MA. Oxidative stress and genotoxic responses to resin acids in Mediterranean mussels. Ecotoxicol Environ Saf. 2005;61(2):221-9. doi: 10.1016/j.ecoenv.2004.12.017.

32. Maria VL, Correia AC, Santos MA. Anguilla anguilla L. genotoxic and liver biotransformation responses to abietic acid exposure. Ecotoxicol Environ Saf. 2004;58(2):202-10. doi: 10.1016/j.ecoenv.2003.12.005.

33. Pacheco M, Santos MA. Induction of EROD activity and genotoxic effects by polycyclic aromatic hydrocarbons and resin acids on the juvenile eel (Anguilla anguilla L.). Ecotoxicol Environ Saf. 1997;38(3):252-9. doi: 10.1006/eesa.1997.1585.

34. Wiseman SB, He Y, Gamal-El Din M, Martin JW, Jones PD, Hecker M, et al. Transcriptional responses of male fathead minnows exposed to oil sands process-affected water. Comp Biochem Physiol C Toxicol Pharmacol. 2013;157(2):227-35. doi: 10.1016/j.cbpc.2012.12.002.

35. He Y, Patterson S, Wang N, Hecker M, Martin JW, El-Din MG, et al. Toxicity of untreated and ozone-treated oil sands process-affected water (OSPW) to early life stages of the fathead minnow (Pimephales promelas). Water Res. 2012;46(19):6359-68. doi: 10.1016/j. watres.2012.09.004. 